\title{
Biogas Desulfurizer Made from Waste of Aluminium Chips
}

\author{
Tjokorda Gde Tirta Nindhia, I WayanSurata, I Ketut Adi Atmika, Dewa Ngakan Ketut Putra Negara, \\ and Gung Putu Adhika Laksmana Putra, Member, IACSIT
}

\begin{abstract}
Hydrogen sulfide $\left(\mathrm{H}_{2} \mathrm{~S}\right)$ is found in the biogas as an impurities. The existence of hydrogen sulfide in the biogas resulting problematic for using biogas as a fuel since it will increase the acidity of the lubricant of the engine. Hydrogen sulfide is a corrosive gas that can corrodes the steel tank of biogas container. Other serious problem concerning $\mathrm{H}_{2} \mathrm{~S}$ is, this type of gas is a harmful gas that should be avoided. This work introduces a technique to utilize aluminium chips waste that is obtained from manufacturing process. To make aluminium chips reactive to $\mathrm{H}_{2} \mathrm{~S}$, the ion $\mathrm{Al}^{3+}$ should be released from the aluminium by galvanic coupling with iron in salt water. The iron uses for this purpose also come from the iron chips waste. It is found the more addition of iron chips in to the mixture of aluminium + iron the more reactive the aluminium as desulfurizer
\end{abstract}

Index Terms-Aluminium, desulfurizer, galvanic coupling, hydrogen sulfide.

\section{INTRODUCTION}

Hydrogen sulfide $\left(\mathrm{H}_{2} \mathrm{~S}\right)$ has to be removed before combusted to prevent environmental problem caused by emission of sulfur (S) compound, for reason of toxicity, and corrosion on equipment [1]. Foam formation was introduce in the early beginning for the removal of $\mathrm{H}_{2} \mathrm{~S}$ from the gas stream [1], but this technique was not attract the customer because the reason of simplicity, especially for the consumer from developing country.

A few years later Lee et al. [2] introduce method of sulfate-resistant Acidithiobacillysthiooxidans AZ11 for removal of $\mathrm{H}_{2} \mathrm{~S}$. This technique also not much attract attention from the consumer because it was not easy to handle the bacteria for this process.

An interesting idea by utilizing waste was introduced by Yuan and Bandosz [3]. The waste that was used come from sewage sludge and metal sludge of various compositions. But this technique becomes not appropriate from economic point of view because the sludge should be pyrolysed at quite high temperature. Similar with work of Yuan and Bandosz [3], which is using waste for desulfurizer, Seredych [4] also using wastes i.e. fly ash for desulfurizer. But this technique become not popular since pyrolyses process is needed at higher temperature $\left(950^{\circ} \mathrm{C}\right)$.

The idea of using natural product such as zeolite as

Manuscript received November 5, 2013; revise February 17, 2014.

The authors are with the Department of Mechanical Engineering, Engineering Faculty, Udayana University Jimbaran, Bali, Indonesia, 80361 (e-mail: nindhia@yahoo.com). desulfurizer was introduced by Cosoli et al. [5]. Zeolite is a mining product with reasonable price but not available every where. Only in certain region we can find zeolite sources from mining. Cost to delivery zeolite from mining location to the place of biogas installation could be another problem.

Recently the research on promoting metal chips waste as desulfurizer was conducted by Nindhia et al. [6]. By utilizing steel chips waste, the regenerative type of desulfurizer can be developed. This type of desulfurizer can be use repetitively and already successful as a component for conversion of gasoline to biogas fueled single cylinder of four stroke engine of electric generator that was invented by Nindhia et al. [7].

In manufacturing industry, the metal waste not only in the form of steel or iron but other type such as aluminium chips waste are much exist since many component of the engine are made from aluminium. Aluminium is not reactive to $\mathrm{H}_{2} \mathrm{~S}$ even though in the form of aluminium oxide as iron oxide in the case of iron. It is the purpose of this research to use the waste of aluminium chips as desulfurizer by using galvanic coupling method. Galvanic coupling is a potential difference that usually exists between two dissimilar metals when they are immersed in conductive solution. This potential difference produce electron flow between them [8] and metal ion will be released from one of the coupling. The metal ion is hopping will react with $\mathrm{H}_{2} \mathrm{~S}$ so that process of desulfurization to occur.

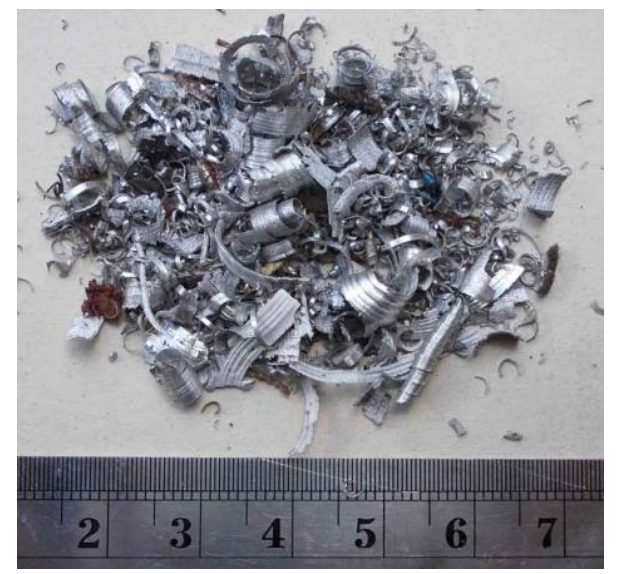

Fig. 1. Waste of aluminium ( $\mathrm{Al})$ chips.

\section{EXPERIMENTAL}

The waste of aluminium (Al) chips was obtained from metal manufacturing industry such as from turning or milling processes as depicted in Fig. 1. The particle size was ignored.

In order galvanic coupling to occur, the aluminium chips were mixed with iron chips. The iron chips were also obtained 
from waste of metal manufacturing industry as can be seen in Fig. 2. It was prepared 4 composition of mixtures (in wt. \%) Namely: $100 \% \mathrm{Al}, 75 \% \mathrm{Al}+25 \% \mathrm{Fe}, 50 \% \mathrm{Al}+50 \% \mathrm{Fe}$, and $100 \% \mathrm{Fe}$.

The mixtures then are put inside water-salt solution ( 250 gram salt in 2 liters of water) for 2 days so that galvanic corrosion to occur. After 2 days in salt water the desulfurizer was taken out and installed as desulfurizer in the system of biogas pipe line. It should be noted that galvanic corrosion will not occur for the mixture of $100 \% \mathrm{Al}$ and $100 \% \mathrm{Fe}$ since only single metal that exist but indeed oxidation occur and will yield aluminium oxide for aluminium and iron oxide for iron.
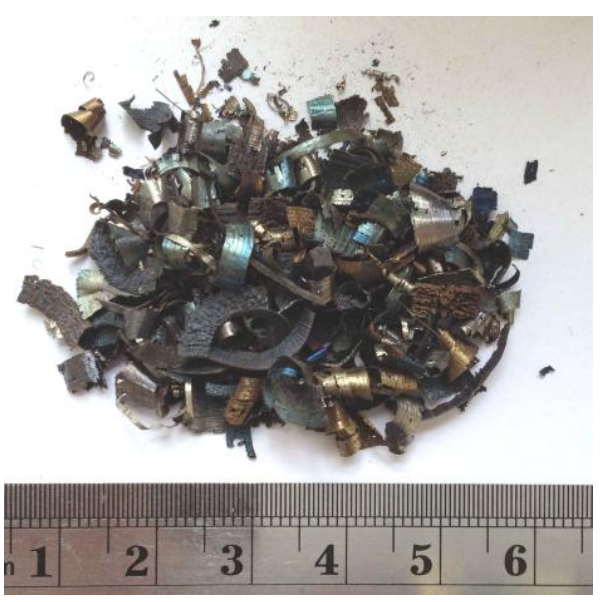

Fig. 2. Waste of iron (Fe) chips.

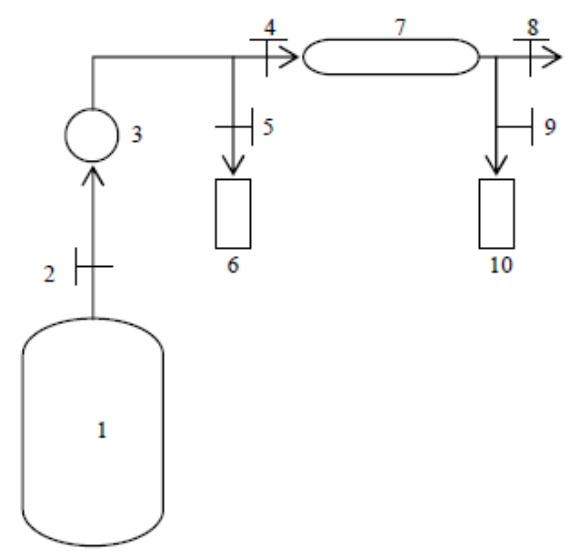

Fig. 3. Schematic of experiment for desulfurizer test performance: 1. Biogas container, 2.Valve, 3.Flow rate indicator, 4. Valve, 5. valve, $6 . \mathrm{H}_{2} \mathrm{~S}$ gas sensor, 7. Desulfurizer, 8. Valve, 9.valve, $10 . \mathrm{H}_{2} \mathrm{~S}$ gas sensor.

It was prepared about 500 gram of each mixture as desulfurizer and installed in the biogas pipe line system. The system was arranged with flow rate about 3 liters/minute. The performance of desulfurizer was evaluated by measuring the $\mathrm{H}_{2} \mathrm{~S}$ contents in the biogas before and after passing the desulfurizer as can be seen in Fig. 3. The performance of desulfurizer was measured for every 5 liters of biogas that passed the desulfurizer and was stopped until reach 50 liter.

The biogas was let flow from gas container 1 and the flow rate was controlled by using valve 2 . The flow rate was checked by using flow rate indicator 3 . To measure the $\mathrm{H}_{2} \mathrm{~S}$ contents in the biogas before entering desulfurizer, the valve 4 was closed and the valve 5 was opened and let the biogas flowed to the $\mathrm{H}_{2} \mathrm{~S}$ gas sensor 6 . If the desulfurizer working well, then the $\mathrm{H}_{2} \mathrm{~S}$ contents in the biogas will decrease and can be measuredby closing valve 8 and open the valve 9 and let the biogas to $\mathrm{H}_{2} \mathrm{~S}$ gas sensor 10 . The performance of desulfurizer then can be calculated by using Equation (1). The result will be presented in graft and analyzed.

$$
\frac{\mathrm{H}_{2} \text { S before desulfurizer }-\mathrm{H}_{2} \mathrm{~S} \text { after desulfurizer }}{\mathrm{H}_{2} \mathrm{~S} \text { before desulfurizer }} \times 100 \%
$$

Laser-induced breakdown spectroscopy (LIBS) was utilized to proof that there is a residue of sulfur in the surface of aluminium and iron during use as desulfurizer of biogas.

\section{RESUlT AND DISCUSSION}

The result is presented in the Fig. 4. It is found that by using $100 \%$ of aluminium chips the performance of desulfurizer is almost zero which is mean that the aluminium, if put in salt water will produce aluminium oxide $\left(\mathrm{Al}_{2} \mathrm{O}_{3}\right)$ which is not reactive to $\mathrm{H}_{2} \mathrm{~S}$ and cannot act as desulfurizer. A Positive indication is found when small amount of iron chips is added $(75 \% \mathrm{Al}+25 \% \mathrm{Fe})$, the performance increase significantly which is above $50 \%$ in reducing amount of $\mathrm{H}_{2} \mathrm{~S}$.

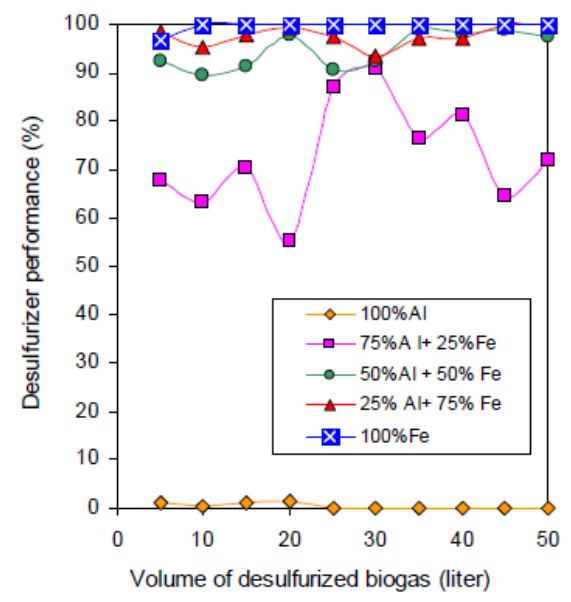

Fig. 4. Performance of aluminium as desulfurizer increase with addition of iron $(\mathrm{Fe})$. Galvanic coupling occur and make aluminium more reactive to $\mathrm{H}_{2} \mathrm{~S}$.

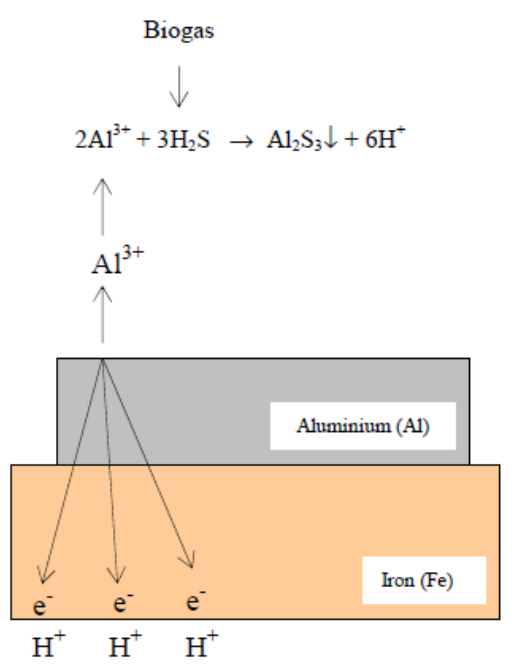

Fig. 5. Schematic reaction of ion $\mathrm{Al}^{3+}$ with $\mathrm{H}_{2} \mathrm{~S}$ from biogas. The ion of $\mathrm{Al}^{3+}$ release from surface of aluminium due to galvanic coupling with iron. 
With addition of iron, so that a mixture of $\mathrm{Al}+\mathrm{Fe}$ is obtained and if this mixture is put in electrolyte of salt water, this condition will make galvanic coupling to occur and aluminium will release the ion $\mathrm{Al}^{3+}$ as can be explained in Fig. 5. The ion $\mathrm{Al}^{3+}$ is reactive to $\mathrm{H}_{2} \mathrm{~S}$ as can be explain in the reaction in the Fig. 5. This reaction will eliminate the $\mathrm{H}_{2} \mathrm{~S}$ impurity in the biogas.

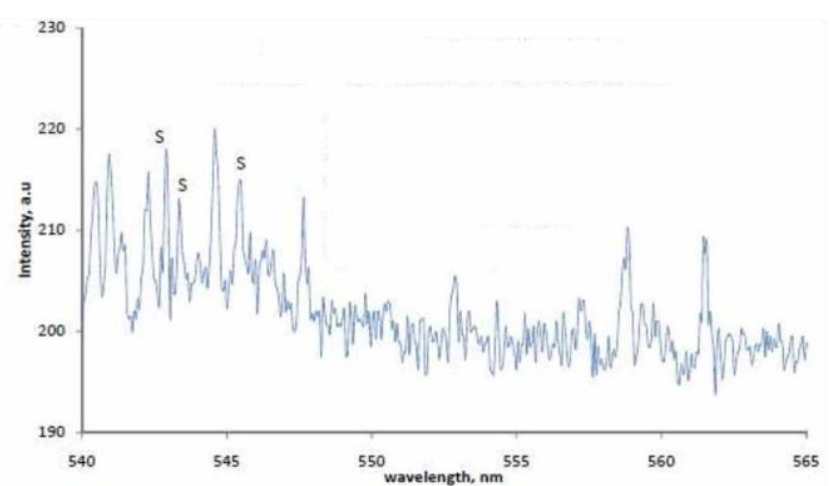

Fig. 6. The surface of aluminium in the micture of $75 \% \mathrm{Fe}+25 \% \mathrm{Al}$. It was found containing sulfur which proof the ability of the aluminium to react with $\mathrm{H}_{2} \mathrm{~S}$ due to galvanic couplig to occur with iron $(\mathrm{Fe})$.

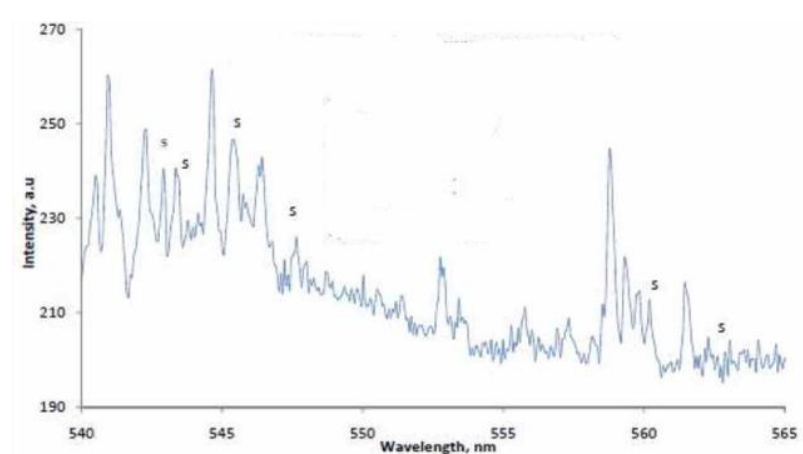

Fig. 7. The surface of iron in the micture of $75 \% \mathrm{Fe}+25 \% \mathrm{Al}$. It was also found containing sulfur which proof that the reaction of $\mathrm{Fe}(\mathrm{OH})_{3}$ with $\mathrm{H}_{2} \mathrm{~S}$ was also occurred.

It is interesting to discuses here that if the iron contents are increase to become $50 \% \mathrm{Fe}$ and similarly happen with $75 \% \mathrm{Fe}$, the reactivity of desulfurizer increase very much and approaching value of $100 \% \mathrm{Fe}$. This condition is achieved because there are two reaction of desulfurization to occur i.e. reaction from $\mathrm{Al}^{3+}$ (proofed in Fig. 6 from LIBS result) and reaction from iron oxide $\left(\mathrm{Fe}(\mathrm{OH})_{3}\right)$. As mixture of $\mathrm{Al}+\mathrm{Fe}$ is put in the salt water in order galvanic coupling to occur. There will be other reaction occur i.e. reaction of iron and salt water to form iron oxide $\mathrm{Fe}(\mathrm{OH})_{3}$ (proofed in Fig. 7 from LIBS result). This iron Oxide is very reactive to $\mathrm{H}_{2} \mathrm{~S}$ [6], [7] as reaction in the (2) bellow:

$$
2 \mathrm{Fe}(\mathrm{OH})_{3}+3 \mathrm{H}_{2} \mathrm{~S} \rightarrow \mathrm{Fe}_{2} \mathrm{~S}_{3}+6 \mathrm{H}_{2} \mathrm{O}
$$

\section{CONCLUSION}

It can be concluded that the waste of aluminium chips is suitable to be used as desulfurizer. The aluminium chips should be mixed with iron in order the galvanic coupling to occur and release ion $\mathrm{Al}^{3+}$. The ion $\mathrm{Al}^{3+}$ is reactive to $\mathrm{H}_{2} \mathrm{~S}$. The galvanic coupling between Aluminium and iron can be done by mixing the aluminium and iron continued by put in the salt water as electrolyte.

\section{ACKNOWLEDGMENT}

The authors wish to thanks the Ministry of National and Culture the Republic of Indonesia for financial support under second phase of national strategic scheme research grant (hibahpenelitianskim strategisnasional) under contract number: 175A.12/UN14.2/PNL.01.03.00/2013 granted through UdayanaUniversity, Jimbaran, Bali, Indonesia

\section{REFERENCES}

[1] W. E. Kleinjan, C. L. Marcelis, A. D. Keizer, A. J. H. Janssen, and M A. C. Stuart, "Foam formation in biotechnological process for the removal of hydrogen sulfide from gas streams," Colloids and Surface A: Physicochem Eng. Aspects, vol. 275, pp.36-44, November 2005.

[2] E. Y. Lee, N. Y. Lee, K. S. Cho, and H. W. Ryu, "Removal of hydrogen sulfide by sulfate-resistant," Journal of Bioscience and Bioengineering, vol.101, no. 4, pp. 309-314, January 2006.

[3] W. Yuanand and T. J. Bandosa, "Removal of hydrogen sulfide from biogas on sludge-derived adsorbents," Fuel, vol. 86, pp. 2736-2746, April 2007.

[4] M. Seredych, C. Strydom, and T. J. Bandosz, "Effect of fly ash addition on the removal of hydrogen sulfide from biogas and air on sewage-based composites adsorbents," Waste management, vol. 28, pp.1983-1992, November 2007.

[5] P. Cosoli, M. Ferrone, S. Pricl, and M. Fermeglia, "Hydrogen Sulphide removal from biogas by zeolite adsorption," Chemical engineering Journal, vol. 145, pp. 86-92, July 2008.

[6] T. G. T. Nindhia, I M. Sucipta, I W. Surata, I K. A. Atmika, D. N. K. P Negara, and K. M. T. Negara, "Processing of steel chips waste for regenerative type of biogas desulfurizer," International Journal of Renewable Energy Research, vol. 3, no. 1, pp. 84-87, 2013.

[7] T. G. T. Nindhia, I W. Surata, I K. A. Atmika, and D. N. K. P. Negara, and A. Wardana, "Method on conversion of gasoline to biogas fueled single cylinder of four stroke engine of electric generator,"Internnational Journal of Environmental Science and Development, vol. 4, no. 3, pp. 300-303, June 2013.

[8] M. G. Fontana, Corrosion Engineering, McGraw-Hill Book Company, ch. 3 , pp.41-42.

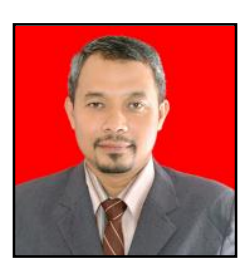

Tjokorda Gde Tirta Nindhia was born in Denpasar, Bali, Indonesia on January $16^{\text {th }}, 1972$. He received his doctor degree in mechanical engineering from Gadjah Mada University (UGM) Yogyakarta, Indonesia on August 2003, with major field of study was material engineering.

He participated in various international research collaboration such as with Muroran Institute of Technology Japan (2004), Toyohashi University of Technology Japan (2006), Leoben Mining University Austria (2008-2009), Technical University of Vienna Austria (2010) and Recently with Institute Chemical Technology of Prague Czech Republic (2012-now). His current job is as a full professor in the field of Material Engineering at Department of Mechanical Engineering, Engineering Faculty, Udayana University, Jimbaran, Bali, Indonesia. His research interest covering subjects such as, biomaterial, waste recycle, failure analyses, ceramic, metallurgy, composite, renewable energy, and environmental friendly manufacturing.

Prof. Nindhia is a member of JICA Alumni, ASEA-UNINET alumni, International Association of Computer Science and Information Technology (IACSIT), Asia-Pacific Chemical, Biological \& Environmental Engineering Society (APCBEES) and also a member of association of Indonesian Nanotechnology. Prof. Nindhia received best researcher award in 1997 and in 2013 from Udayana University the place where he is working and again in 2012 received both Best researcher award from Engineering Faculty of Udayana University . In 2013 Prof. Nindhia awarded as 15 best performance Indonesian lecturers from Ministry of Education and Culture The Republic of Indonesia.

I Wayan Surata was born in Nusa Penida, Bali, Indonesia on July 5, 1958, who received the doctor degree in the field of ergonomic from Udayana 
University in 2011. His research interest very much related in process of manufacture. He is currently working as a researcher and lecturer at Department of Mechanical Engineering, Engineering Faculty, Udayana University, Jimbaran, Bali, Indonesia.

I Ketut Adi Atmika was born in Negara, Bali, Indonesia on May 18, 1969. $\mathrm{He}$ received his master degree in mechanical engineering from Institute Technology of Sepuluh November, Surabaya, Indonesia. He is currently working as a researcher and lecturer at the Department of Mechanical Engineering, Engineering Faculty, Udayana University, Jimbaran, Bali, Indonesia.
Dewa Ngakan Ketut Putra Negara was born in Payangan, Bali, Indonesia on June 13, 1971. He received hisM.Sc from University of Bradford, UK in 2001 in manufacturing systems engineering and management. He is currently working as a researcher and lecturer at the Department of Mechanical Engineering, Engineering Faculty, Udayana University, Jimbaran, Bali, Indonesia.

Gung Putu Adhika Laksmana Putra was an undergraduate student at the Mechanical Engineering Department, Udayana University, Jimbaran, Bali, Indonesia and graduated in 2012. 